\title{
Preference and Consumption Pattern of Horticultural Species in the Offshore Homestead Forest of Bangladesh
}

Kazi Mohammad Masum ${ }^{1, *}$, Abdullah Al Mamun², Mohammad Mamun-Or-Rashid ${ }^{3}$, M. M. Abdullah-Al-Mamun ${ }^{4}$ and Mohammad Nabidul Islam ${ }^{5}$

${ }^{1}$ Department of Forestry and Environmental Science, Shahjalal University of Science and Technology, Sylhet, Bangladesh

${ }^{2}$ Department of Environment, Bangladesh

${ }^{3}$ Institute of Forestry and Environmental Sciences, Chittagong University, Chittagong, Bangladesh

${ }^{4}$ Research Assistant, IUCN - The World Conservation Union, Bangladesh Country Office, Dhaka, Bangladesh

${ }^{5}$ Department of Forestry and Environmental Science, Shahjalal University of Science and Technology, Sylhet, Bangladesh

\begin{abstract}
An explanatory survey was conducted to assess preference and consumption pattern of horticultural species, their sources, location-wise planting preferences and diversity of these species in the rural homestead forest of the offshore island of Bangladesh. Assessment was done through multistage random sampling. Based on homestead size respondents were categorized into small $(<0.05 \mathrm{ha})$, medium $(0.05-0.25 \mathrm{ha})$ and large $(>0.25 \mathrm{ha})$ and twenty from each category were selected randomly for the study. The study revealed that most of the farmer (75.5\%) preferred to plant fruit tree species for future plantation followed by timber species (62.2\%). But fruit-bearing plants were being gradually replaced by some exotic timber species such as Swietenia mahagoni, Acacia auriculiformis, Tectona grandis, Eucalyptus spp., etc. Diversity and abundance of fruit species was found higher in almost all homestead. A total of 41 horticultural species were identified and seven horticultural species among them were recognized as the most preferred ones in the study area. Consumption pattern was chiefly to meet the nutritional demand and to gain a quick monetary benefit. Average annual income from horticultural species was 7,183.33 Taka (US\$102).
\end{abstract}

Key Words: preference, horticultural species, diversity, offshore island, Bangladesh

\section{Introduction}

Man's dependence on plants for his existence dates back to the beginning of the human race. Now-a-days man depends heavily on a large variety of plants to meet their daily needs of several products. Vegetation survey conducted on traditional homegardens in four regions (Deltaic, Dry Land, Hilly and plain) in Bangladesh revealed that a total of 92 perennial species ( 67 species for Deltaic region, 56 for
Plain region, 56 for Hilly region and 46 for Dryland region) were recorded for the set of 80 homegardens surveyed (Millat-e-Mustafa 1997). Predominance of Mango (Mangifera indica), Jackfruit (Artocarpus heterophyllus), Coconut (Cocos nucifera) and other fruit trees in nearly all homesteads throughout the country indicates a preference for fruit trees among most people (Abedin et al. 1988).

Bangladesh is situated at the complex interface of Himalayan and Southeast Asian Bio-geographic regions,

Received: March 29, 2012. Revised: May 9, 2012. Accepted: May 10, 2012.

Corresponding author: Kazi Mohammad Masum

Department of Forestry and Environmental Science, Shahjalal University of Science and Technology, Sylhet 3114, Bangladesh Tel: 880-01816052842, Fax: 880-821-715257,E-mail: kmmasum-for@sust.edu 
and historically was well endowed with very diverse complements of terrestrial and aquatic flora and fauna (Quamrul 2001). Homestead forest in Bangladesh covers an area of 0.27 million ha. (Occupied by 15.4 million homesteads) while state owned forests cover 2.25 million ha (Mukul et al. 2008).

Homestead forestry, popularly known as homegarden, is an important component of rural economy of Bangladesh as well as in the tropical region of the world. Growing of variety of trees, shrubs, herbs and aerial plants around homesteads is an age-old practice in this country (Abedin and Quddus 1990). Diversity and abundance of fruit species was found higher in all homestead in comparison with other species like timber, fruit, medicinal etc. (Millat-e-Mustafa 1997). Rural people can best understand their prime needs, and the composition of homestead fruit species usually represents their need and knowledge base for the management of such forests. Hence, understanding homestead woodlots are important for forest managers, rural development organizations, researchers as well as politicians for effective forestry planning and subjective policy making.

Different aspect of horticultural species was studied by different authors (Akhter et al. 1989; Islam et al. 1990; Miah et al. 1990; Khan 1991) at different agro-ecological zones of Bangladesh which have acknowledged the predominance of fruit and food producing species in the homegardens. But, no study was so far carried out solely to assess household level consumption pattern and preference of horticultural species in rural households of the offshore island of Bangladesh. Because of transportation difficulties with the main land, people of the offshore island heavily depend on their homegarden's product. Moreover, fruits of neighboring countries has occupied major portion of the fruit market due to indiscriminate removal of vegetation in general, and the cutting of trees over the years for the households and other purposes. Isolated studies reveal that about 31 minor fruit species, have reached a stage of near extinction (Ahmed 1994). Thus the present study focuses preference and consumption pattern of horticultural species and the problems and remedial measures in relation to raising and management of horticultural species in the rural homegarden of the offshore island of Bangladesh.

\section{Materials and Methods}

Sandwip is on the Bay of Bengal occupying an area of $762.42 \mathrm{~km}^{2}$ (BBS 2011). The ecological hazards hitting the area are frequently cyclones and storm surges of various intensities and exceptionally high tides resulting in salt water flooding of agricultural lands. The size and shape of households are decreasing due to land erosion by river, population growth and modernization. Again the potentiality of home gardening is limited to some extent due to salinity. Field investigations were conducted over a period of six months (July-December, 2010). Sandwip lies between latitude $22^{\circ} 22^{\prime} \mathrm{N}$ and $22^{\circ} 43^{\prime} \mathrm{N}$ and longitude $91^{\circ} 18^{\prime} \mathrm{E}$ and $91^{\circ} 34^{\prime} \mathrm{E}$ (Fig. 1). According to statistical pocket book, Bangladesh 2010, total households of the upazila was 43292 (BBS 2003). Among 20 upazillas (Sub-district) of Chittagong district, Sandwip upazila was selected purposively as it was the only offshore island of the district, suitably representing the identical feature of offshore island areas of Bangladesh. Two unions were selected randomly for the study out of 19 unions in Sandwip upazilla. From every union, one village forming a total of two villages viz, Harishpur and Musapur were selected. Homegarden size (the area, a household occupy) was used as the basic for stratification. The homestead sizes of the study area were classified into 3 groups viz, large $(>0.25 \mathrm{ha})$, medium (0.05-0.25 ha) and small ( $<0.05 \mathrm{ha})$ based on the result obtained from a preliminary survey using pre-tested questionnaire on the socioeconomic status of the households. The households from each selected union were randomly selected from a list of household according to farm size provided by Upazilla Porishad. A total of 60 households, 20 from each group (i.e. 10 of each group from each of the two villages), were taken to represent the real situation with help of semi-structured questionnaires (that was surveyed door to door).

Data on preference and consumption pattern of horticultural species, their sources, location wise planting preferences, diversity and frequency etc. were collected through interview using questionnaire. Density, Relative density as a quantitative structure, the Shanon-Winner index for diversity (Michale 1990), Diversity index (Odum 1971) as a measure of diversity were evaluated. Species Richness index and Species evenness index were also calculated using for- 


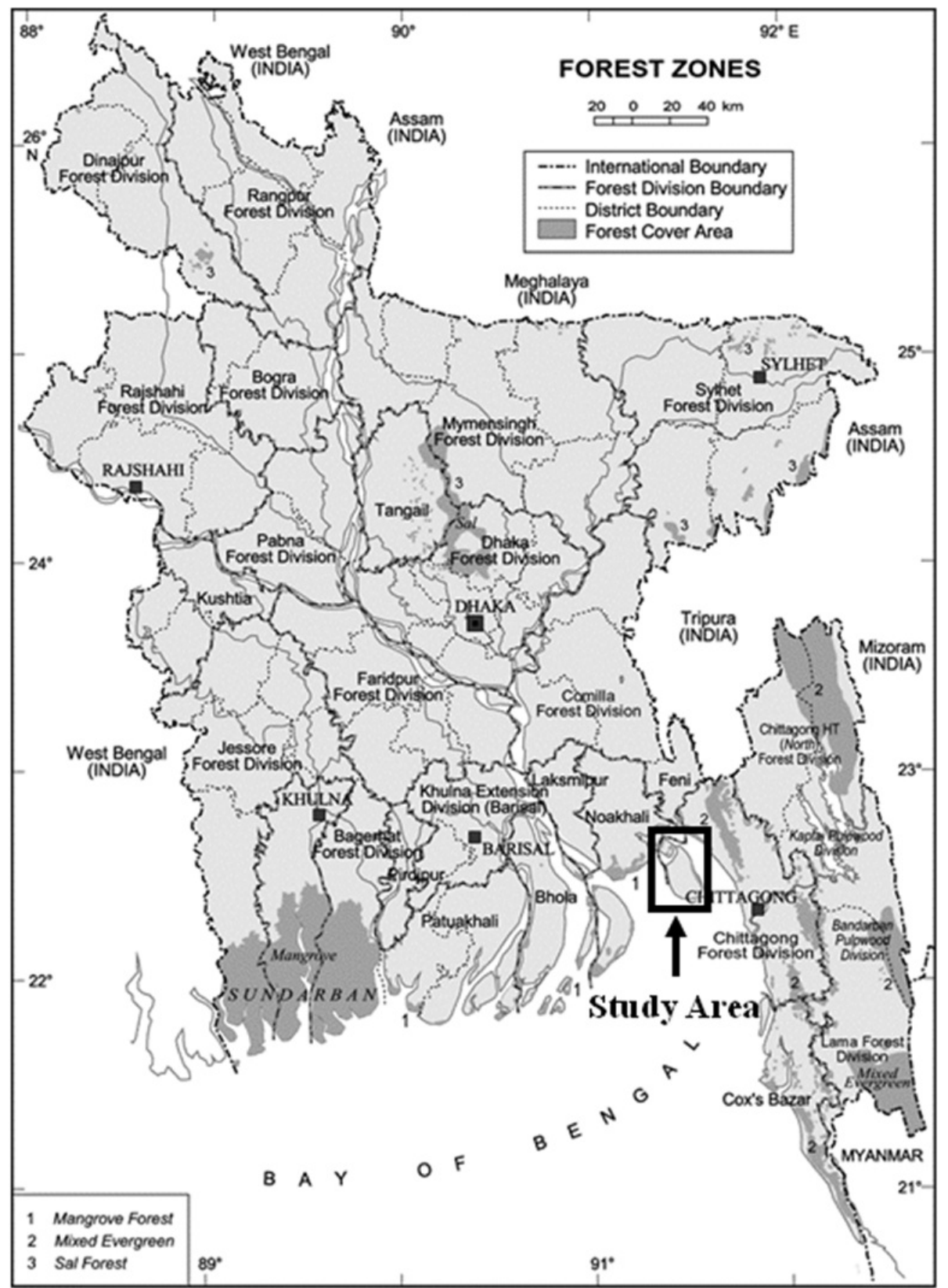

Fig. 1. Map of Bangladesh showing the study area (Source: Banglapedia 2003). mula given by Margalaf (1958) and Pielou (1966).

1. Density of a species $=$

Total no. of individuals of a species in all the quadrates Total no. of quadrates studied

2. Relative density of a species $=$

Total no. of individuals of a species in all the quadrates Total no. of quadrates studied
Where, $\mathrm{H}=$ Index of species diversity, $\mathrm{Pi}=$ No. of individual of one species / Total no. of individuals in the samples

4. Diversity index, $D=S / N$

Where, $\mathrm{D}=$ Diversity Index, $\mathrm{S}=$ Total number of species, $\mathrm{N}=$ Total number of individuals

5. Species richness index, $R=(S-1) / \log N$

Where, $\mathrm{R}=$ Species richness index, $\mathrm{S}=$ Total no. of species, $\mathrm{N}$ $=$ Total no. of individuals of all the species

3. The Shanon-Winner index for diversity, $\mathrm{H}=-\sum \mathrm{Pi}^{*} \ln \mathrm{Pi}$ 
Table 1. List of identified fruit trees in the study area.

\begin{tabular}{|c|c|c|c|c|c|c|}
\hline Serial no. & Family name & Serial no. & Scientific name & Local name & Density & Relative density, $\mathrm{Pi}$ \\
\hline \multirow[t]{4}{*}{1} & Anacardiaceae & 1 & Mangifera indica $\mathrm{L}$. & Am & 15.783 & 0.1363 \\
\hline & & 2 & Buchanania lanzan Spreng. & Piyal & 0.133 & 0.0012 \\
\hline & & 3 & Spondias pinnata (L.f.) Kurz. & Amra & 0.733 & 0.0063 \\
\hline & & 4 & Annas comosus & Pineapple & 1.100 & 0.0095 \\
\hline \multirow[t]{2}{*}{2} & Annonaceae & 5 & Annona muricata L. & Attafal & 1.133 & 0.0098 \\
\hline & & 6 & Annona squamosa $\mathrm{L}$. & Sorifa & 0.050 & 0.0004 \\
\hline 3 & Caricaceae & 7 & Carica papaya Linn. & Papaya & 2.400 & 0.0207 \\
\hline 4 & Dilleniaceae & 8 & Dillenia indica Linn. & Chalta & 0.450 & 0.0039 \\
\hline \multirow[t]{2}{*}{5} & Ebenaceae & 9 & Diospyros discolor Wild. & Bilati Gab & 0.400 & 0.0035 \\
\hline & & 10 & Diospyros peregrina & Deshi Gab & 2.850 & 0.0246 \\
\hline 6 & Elaeocarpaceae & 11 & Elaeocarpus robustus Roxb. & Jalpai & 0.617 & 0.0053 \\
\hline \multirow[t]{2}{*}{7} & Euphorbiaceae & 12 & Cicca acida (Linn.) Merr. & Arboroi & 0.117 & 0.0010 \\
\hline & & 13 & Phyllanthus emblica Linn. & Amloki & 0.383 & 0.0033 \\
\hline 8 & Guttiferae & 14 & Garcinia cowa Roxb. & Као & 0.417 & 0.0036 \\
\hline 9 & Leguminosae & 15 & Tamarindus indica Linn. & Tentul & 0.883 & 0.0076 \\
\hline \multirow[t]{3}{*}{10} & Moraceae & 16 & Artocarpus lakoocha Roxb. & Dewa/Barta & 0.883 & 0.0076 \\
\hline & & 17 & Artocarpus heterophyllus & Kanthal & 7.417 & 0.0641 \\
\hline & & 18 & Ficus racemosa $\mathrm{L}$. & Jagya-dumur & 0.200 & 0.0017 \\
\hline \multirow[t]{5}{*}{11} & Myrtaceae & 19 & Syzygium fruticosum Roxb. & Putijam & 0.983 & 0.0085 \\
\hline & & 20 & Eugenia javanica Lamk. & Jamrul & 0.267 & 0.0023 \\
\hline & & 21 & Syzygium cumini Linn. & Jam & 1.600 & 0.0138 \\
\hline & & 22 & Psidium guajava Linn. & Peyara & 3.083 & 0.0266 \\
\hline & & 23 & Eugenia jambos L. & Golabjam & 0.117 & 0.0010 \\
\hline 12 & Oxalidaceae & 24 & Averrhoa carambola Linn. & Kamranga & 0.917 & 0.0079 \\
\hline \multirow[t]{4}{*}{13} & Palmae & 25 & Phoenix sylvestris (L.) Roxb. & Khejur & 2.517 & 0.0217 \\
\hline & & 26 & Borassus flabellifer Linn. & Tal & 1.283 & 0.0111 \\
\hline & & 27 & Cocos nucifera Linn. & Narikel & 18.200 & 0.1572 \\
\hline & & 28 & Areca catechu Linn. & Supari & 24.117 & 0.2083 \\
\hline 14 & Rhamnaceae & 29 & Ziziphus jujuba Linn. & Boroi & 2.517 & 0.0217 \\
\hline 15 & Rosaceae & 30 & Pyrus malus L. & Apple & 0.067 & 0.0006 \\
\hline \multirow[t]{7}{*}{16} & Rutaceae & 31 & Aegle marmelos Linn. & Bel & 0.400 & 0.0035 \\
\hline & & 32 & Citrus grandis (Linn.) Osbek. & Jambura & 1.183 & 0.0102 \\
\hline & & 33 & Citrus reticulata Blanco. & Kamala & 0.133 & 0.0012 \\
\hline & & 34 & Citrus limon (Linn.) Burm.f. & Lebu & 1.817 & 0.0157 \\
\hline & & 35 & Citrus jambhiri L. & Alachi Lebu & 0.083 & 0.0007 \\
\hline & & 36 & Feronia limonia & Kadbel & 0.133 & 0.0012 \\
\hline & & 37 & Litchi chinensis Sonn. & Litchi & 0.467 & 0.0040 \\
\hline 17 & Sapindaceae & 38 & Achras zapota Linn. & Sofeda & 0.050 & 0.0004 \\
\hline 18 & Sapotaceae & 39 & Punica granatum Linn. & Dalim & 0.317 & 0.0027 \\
\hline 19 & Punicaceae & 40 & Musa sapientum & Aitta kola & 6.433 & 0.0556 \\
\hline 20 & Musaceae & 41 & Musa paradisiaca & Kacha kola & 4.817 & 0.0416 \\
\hline
\end{tabular}

6. Species evenness index, $E=H / \log S$

Where, $\mathrm{E}=$ Species evenness index, $\mathrm{H}=$ Shanon-Winner index of diversity, $\mathrm{S}=$ Total no. of species

Finally a paired ranking exercise was also conducted to find out the respondent's preference for different fruit species. 


\section{Result and Discussion}

\section{Horticultural species composition}

Homegardens of the study area were found rich in horticultural species. A total of 41 species consisting 20 families were identified in the study area (Table 1). Family Rutaceae consists of maximum no. of species (7) which is followed by Myrtaceae (5), Palmae (4) and Anacardiaceae (4) etc. Cocos nucifera, Areca catechu, Psidium guajava, Musa spp., Carica papaya, Phoenix sylvestris, Mangifera indica was cultivated in more than $75 \%$ of the homestead. The farmers concentrate on fruit species because of their subsistence and cash need. Multipurpose nature of fruit tree is a major determining factor in this case.

\section{Diversity and Density of fruit trees in the home- garden}

Data obtained from Shanon Winner diversity index (2.53) show higher value than Index of Dominance (0.09) for the horticultural species of the study area which represents less dominancy of the fruit tree species with more diversity in the homegarden. The calculated value of Species Richness Index and Species Evenness Index was 10.50 and 1.57 respectively which represent the more richness of fruit tree species (corroborated with the previous findings) and more evenly the total number of individuals is distributed among all possible fruit tree species (Table 2). Fruit species density and frequency varies from homegarden to homegarden and also within the same homegarden in different locations. The highest value of density and relative density was counted (24.117 and 0.2083 respectively) for Areca catechu followed by Cocos nucifera (18.200 and 0.1572), Mangifera indica (15.783 and 0.1363) etc. On the other hand the lowest value of density and relative density was accounted as 0.05 and 0.0004 respectively for both Annona squamosa and Achras zapota (Table 1).

\section{Locationwise planting preferences}

Rural households plant fruit trees in different locations of the homegarden without any scientific considerations Among the identified 41 fruit species $87.80 \%$ species were observed around house, $63.41 \%$ in pond bank, $53.66 \%$ in marginal land and $31.71 \%$ in other places (Table 3 ). The reasons behind people's more preferences on the 'house surrounding' for planting fruit trees may be the convenience in terms of proximity to the living quarter, protection against theft and ease of management. Similar observations were also reported by Fernandes and Nair (1986) from the Wickramasinghe (1992) from the Kandy homegardens of Srilanka. Preferences in selecting species for different parts of their Homegardens vary with farmer's taste and attitude.

\section{Preference of horticulture species}

The reasons for growing a variety of fruit species in the homegarden and farmers preferences in growing certain

Table 3. Distribution of fruit species in different positions of the homegarden

\begin{tabular}{lccc}
\hline \multicolumn{1}{c}{ Location } & $\begin{array}{c}\text { Total no. of } \\
\text { species recorded }\end{array}$ & $\begin{array}{c}\text { Total species } \\
\text { counted in all } \\
\text { homegardens }\end{array}$ & $\begin{array}{c}\text { Percentage } \\
(\%)\end{array}$ \\
\hline Around house & 36 & 41 & 87.80 \\
Pond bank & 26 & & 63.41 \\
Marginal land & 22 & & 53.66 \\
Others & 13 & & 31.71 \\
\hline
\end{tabular}

Table 2. Diversity and density analysis of the horticultural species in the study area

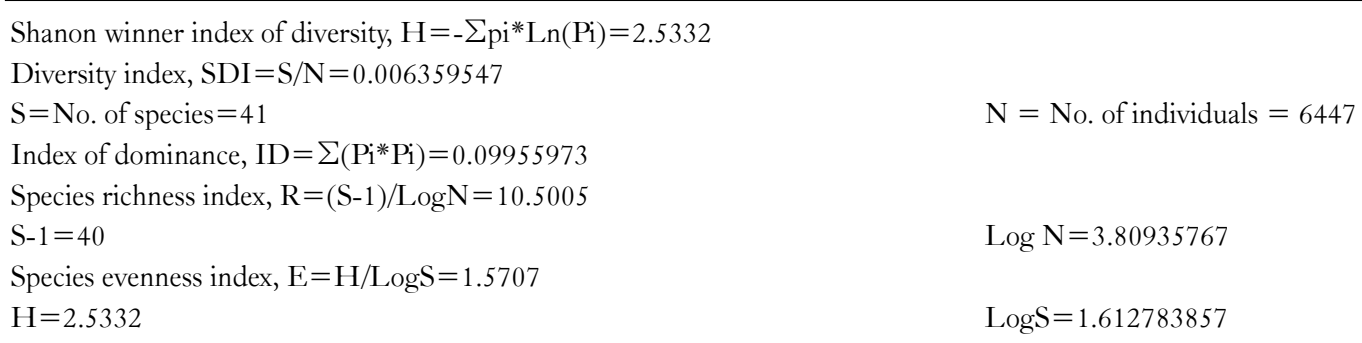


trees are more and less complex. Though farmer's preferences on fruit species varied among different household categories, a number of species (e.g. Mangifera indica, Artocarpus heterophyllus, Cocos nucifera and Areca catechu) were always preferred by farmers of all categories. Geographical location, age of the holdings, nature of the principle wage earner and of the family members, availability of planting materials, availability of space, commercial value etc. may be the guiding factors affecting farmers' species preferences in the study area. These findings are also supported by the study of Millat-e-Mustafa (1997) for the homegardens of four regions in Bangladesh.

Thus households representing different farm groups did not have equal access to same fruit source. The large household owners had the ability to buy fruit from the market and they did not bother for the fruit supply available from their homesteads, even though they had larger homesteads than those in the other farm groups. People in the medium category utilize fully all the fruit resources from their homesteads. They maintain a keen observation towards their homegarden's fruit species to save from theft. As the small households were mostly poor, they did not have enough space for homesteads. To fulfill their demand for fruit they had to wait for the cheap period of a particular fruit. It was also found that the higher income group has a soft feeling for the neighboring poor family in providing them an access to their homegarden fruit resources.

Finally from paired ranking exercise it was identified that se fruit species were the most preferred by the respondents. Mangifera indica was the most preferred fruit tree species followed by Cocos nucifera, Artocarpus heterophyllus, Carica papaya, Phoenix sylvestris, Musa spp. and Supari Areca catechu (Fig. 2). Availability, price, taste and space are the main factor that acts as the determinant of preference to the small

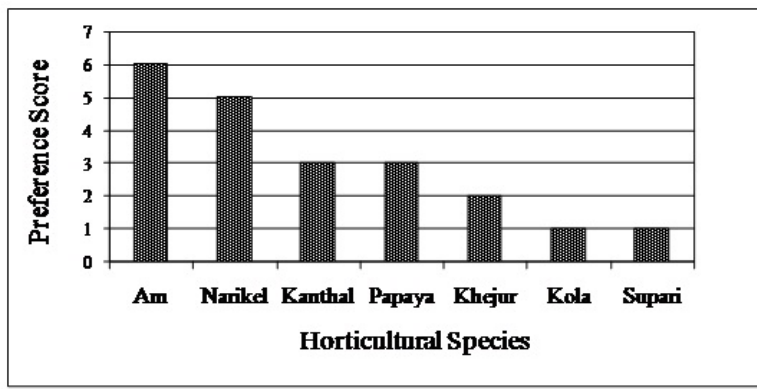

Fig. 2. Preferred Horticultural species by the rural households in the study area.

Table 4. Preference percentage of planting materials for fruit tree rising in the homegardens of the study area

\begin{tabular}{clccr}
\hline \multirow{2}{*}{ Location } & Household category & \multicolumn{3}{c}{ Preference (\%) } \\
\cline { 3 - 5 } & & Seed & Seedling & Vegetative propagules \\
\hline \multirow{2}{*}{ Harishpur union } & Large & 54 & 68 & 21 \\
& Medium & 56 & 48 & 4 \\
\multirow{3}{*}{ Musapur union } & Small & 82 & 38 & 2 \\
& Large & 56 & 60 & 29 \\
\multirow{2}{*}{ Mean } & Medium & 42 & 56 & 26 \\
& Small & 68 & 22 & 25 \\
& Large & 55 & 64 & 15 \\
& Medium & 49 & 52 & 5 \\
\hline
\end{tabular}

Table 5. Percentage distribution of planting material sources

\begin{tabular}{lcccccc}
\hline \multirow{2}{*}{ Planting material } & \multicolumn{5}{c}{ Percentage } \\
\cline { 2 - 7 } & Self raised & Neighbor & Private nursery & Govt. nursery & Tree fair & Market \\
\hline Seed & 84 & 11 & - & - & - & 5 \\
Seedling \& vegetative propagules & 56 & 4 & 6 & 8 & 2 & 24 \\
\hline
\end{tabular}


and medium farm category.

\section{Planting materials preferred for fruit tree raising in homegardens}

The study indicates that farmers have intimate knowledge about different techniques of raising plantations. In planting fruit trees, village people prefer mainly three types of planting materials: seed, seedling and vegetative propagules. In case of some fruit species like Carica papaya, Cocos nuifera, Areca catechu, etc. seedlings are mostly raised by themselves within homegardens. In the study area within the large category highest preference was for seedling as a planting material. This is because of the availability of seedling in the nearby nursery. But in the medium category though seedling (52\%) got higher preferences, preference of seed (49\%) was not far behind as they have to pay more attention to the financial aspect in every deed (Table 4). To the poor or small household category seed collected from the neighboring household was the main source of planting materials. Vegetative propagules were not so available because of lack of expertise. Finally ease of availability, quality, more survival rate, convenient size etc. may be the criteria in choosing the

Table 6. Problems faced by the household in raising trees in the study area

\begin{tabular}{lc}
\hline \multicolumn{1}{c}{ Farm category } & \% of respondent \\
\hline Damaged by animals & 53 \\
Damaged by storm & 51 \\
Damaged by pest and insects & 27 \\
Damaged by children & 22 \\
Lack of technical knowledge & 18 \\
Unavailability of space & 11 \\
Stolen & 11 \\
No problems & 7 \\
\hline
\end{tabular}

planting materials. Specific type of planting material gets most preference in planting for a particular fruit tree.

\section{Sources of planting materials}

The farmer themselves raises most of the planting materials required in raising fruit trees in their homegardens. Almost $84 \%$ of seed and $56 \%$ of seedlings of fruit trees are raised by the farmers themselves (Table 5). Market provides $24 \%$ of the seedling requirement for the household. Neighbor, private nursery, Government nursery and the annual tree fair are the main source of the rest of the seedlings and vegetative propagules.

\section{Causes responsible for felling of fruit trees}

In almost all the homegarden, it was observed that people practices felling of fruit trees in order to fulfill different types of their livelihood necessities. Within all the age categories the most common reasons behind these felling were identified as natural calamities $\&$ house extension. Other causes were cash need in crises period, fruit wood, furniture making, to meet marriage expenditure, house-making items etc.

\section{Problems in raising fruit trees}

Fruit tree raising and management within the homegardens are affected by several reasons. Among them, the most dominant one which belongs to almost all the age categories are 'damage by animals, due to which fruit trees cannot be raised successfully to meet the existing fruit demand of the country (Table 6). Animals were reported to eat leaves and branches of trees, and trample the seedling and saplings. Seedling were also damaged by storm $(51 \%)$, pest and insects (27\%) and by children (22\%). Lack of technical knowledge, unavailability of space and losses by stealing were also encountered as tree management problem.

Table 7. Distribution of income from horticultural species according to farm category (Tk./ Year)

\begin{tabular}{lcccc}
\hline \multicolumn{1}{c}{ Household category } & Small & Medium & Large & Average \\
\hline Harishpur union & 2755.00 & 6480.00 & 12950.00 & 7395.00 \\
Musapur union & 2345.00 & 6520.00 & 12050.00 & 6971.66 \\
Income from household (Tk/Year) & 2550.00 & 6500.00 & 12500.00 & 7183.33 \\
\hline
\end{tabular}

* US $\$ 1=70.00 \mathrm{Tk}$. 


\section{Rare fruit species in the study area}

Among the surveyed 60 homegardens, Achras zapota and Annona squamosa were found only in one homegarden both from large and medium category. These might because of lack of awareness and interest in planting. Pyrus malus and Citrus reticulate were recently introduced in two homegardens of large and medium category, but not found in small homegardens as people think these are more valuable than other fruit species. The present study revealed that traditional fruits of low economic value gradually being replaced by some exotic timber species such as Swietenia mahagoni, Acacia auriculiformis, Tectona grandis and Eucalyptus spp. etc. Ahmad and Islam (1994) indicated in that about 31 minor fruit species, have reached a stage of near extinction from the home in Bangladesh. No Strategy and policy has yet been taken by government or non-government institution to preserve the indigenous and minor species from the verge of extinction.

\section{Income from horticultural species}

Farmers benefited from homegarden in several ways. Homegarden fruit diversity act as a "reserve bank" of food and cash for farmers. Average annual income from horticultural species was 7183.33 Taka (US\$102). Income from fruit species diversity was significantly different within the farm categories. It was observed that the medium farmers intensively cultivated the homegarden (Table 7). This might be the reason for getting more income from their homegarden.

\section{Conclusions}

The homegarden is a good niche of multipurpose trees and shrubs. It is integrated part of family subsistence living. In Bangladesh about $49 \%$ people live below poverty line who are seriously affected from malnutrition and different diseases. Producing various nutritious foods around house is an important way of providing adequate and ready supply of food to the household members. Thus, selective plantation of fruit species in and around the homegarden can greatly influence the promotion of proper nutrition. Farmers are mostly concerned about improving the growth of the fruit trees in their homegardens. There are still im- mense scopes to improve technologies for species selection, clonal propagation, study on species interactions, soil management techniques, etc. Finally, in order to achieve a stable ecological balance and sustainable productivity of homegarden we should take proper initiative to re-introduce the rare indigenous fruit trees and carefully manage the existing fruit trees in the homegarden through improved management techniques.

\section{References}

Abedin MZ, Quddus MA. 1990. Household Fuel Situation, Homegardens and Agroforestry Practice at Six Agro-Ecologically Different Locations of Bangladesh. In: Homestead Plantation and Agroforestry in Bangladesh (Abedin MZ, Lai C, Ali MO, eds). BARI/FAO/WINROCK, Joydebpur, Bangladesh, pp 19-53.

Abedin Z, Aktar S, Haque F, Alam S. 1988. Use of Multipurpose Trees on the Small Farms of the Low-Rainfall Ganges Floodplain Soil of Bangladesh. In: Multipurpose Tree Species for Small-Farm Use (Withington D, McDicken KG, Sastry $\mathrm{CB}$, Adams NR, eds). WINROCK and IDRC, Canada, pp 31-47.

Ahmed MR, Islam A. 1994. People's Choice and Attitudes Towards Growing Multipurpose Tree Species, Chittagong University Studies, Part II: Science. 18: 31-37.

Akhtar MS, Abedin MZ, Quddus MA. 1989. Why Farmers Grow Trees in Agricultural Fields: Some Thoughts, Some Results. Research report 1988-89. On-farm Research Division, BARI, Joydebpur, Bangladesh, pp 161-178.

Banglapedia. 2003. National Encyclopedia of Bangladesh. In: Asiatic Society of Bangladesh (Islam S, ed). Nimtali, Dhaka, Bangladesh, pp 105-106.

BBS (Bangladesh Bureau of Statistics). 2003. Overview: NationalSeries. Bangladesh Population Census, Ministry of Planning. Government of Peoples Republic of Bangladesh, Dhaka, Bangladesh.

Fernandes ECM, Nair PKR. 1986. An Evaluation of the Structure and Function of Tropical Homegardens. Agricultural Systems 21: 279-310.

Islam MB, Mannaf MA, Karim MR, Chowdhury SA, Karim MR, Abedin MZ, Khair ABMA. 1990. Rural Fuel Supply, Homestead Plantation and Agroforestry System on the Highlands of Tista Flood Plain Area. In: Homestead Plantation and Agroforestry in Bangladesh (Abedin MZ, Lai C, Ali MO, eds). BARI/FAO/WINROCK, Joydebpur, Bangladesh.

Khan SH. 1991. Agroforestry Research and Development in Bangladesh-a Brief Overview. Chittagong University Studies, Part II: Science. 18: 154.

Margalef R. 1958. Temporal Succession and Spatial Heterogeneity 
in Phytoplankton. In: Perspective in Marine Biology (Traverso AAB, ed). University of California Press, Berkeley, pp 470.

Miah G, Abedin MZ, Khair ABMA, Shahidullah M, Baki AJMA. 1990. Homestead Plantation and Household Fuel Situation in Ganges Floodplain of Bangladesh. In: Homestead Plantation and Agroforestry in Bangladesh (Abedin MZ, Lai C, Ali MO, eds). BARI/FAO/WINROCK, Joydebpur, Bangladesh, pp 120-135.

Michael P. 1990. Ecological Methods for Field and Laboratory Investigation. Teta Mc-Graw Hill Publishing Co. Ltd., New Delhi, pp 404.

Millat-e-Mustafa M. 1997. Tropical Homegardens: An Overview. In: Agroforestry: Bangladesh Perspective (Alam MK, Ahmed FU, Amin SMR, eds). APAN/NAWG/BARC, Dhaka,
Bangladesh, pp 18-33.

Mukul SA, Uddin MB, Uddin MS, Khan MASA, Marzan B. 2008. Protected Areas of Bangladesh: Current Status and Efficacy for Biodiversity Conservation. Proceedings of the Pakistan Academy of Sciences 45: 59-68.

Odum EP. 1971. Fundamentals of Ecology. 3rd ed. WB Saunders and C, Phiadelphia, pp 574.

Pielou EC. 1966. Species Diversity and Pattern Diversity in the Study of Ecological Succession. J Theor Biology 10: 370-383.

Quamrul IC. 2001. Bangladesh State of Bio-Diversity. Forum of Environmental Journalist of Bangladesh, Dhaka, Bangladesh.

Wickramasinghe A. 1992. Village Agroforestry Systems and Tree use Practice: A Case Study in Sri Lanka, Report No.17, F/FRED Project, Bangkok, Thailand. 